\title{
Could Microparticles and PD1 Interplay Add More Effects on Treatment Outcomes of Multiple Myeloma? A Prospective Controlled Study
}

\author{
Asmaa Zahran \\ Assiut University \\ Zeinab Albadry Zahran \\ Assiut University \\ Amal Rayan ( $\sim$ amalrayan@aun.edu.eg ) \\ Assiut University
}

\section{Research Article}

Keywords: Multiple Myeloma, Microparticles, CD138+microparticles, PD1, remission

Posted Date: January 23rd, 2021

DOl: https://doi.org/10.21203/rs.3.rs-148921/v1

License: (1) This work is licensed under a Creative Commons Attribution 4.0 International License. Read Full License 


\section{Abstract}

Background: Although multiple myeloma (MM) is still considered as an incurable disease by current standards, the development of several combination therapies, and immunotherapy approaches has raised the hope towards transforming MM into an indolent, chronic disease, and possibly achieving a cure.

Objectives: We tried to shed light on the expression of PD1 and different Microparticles (MPs) in MM and their interplay as a mechanism of resistance to standardized treatments, in addition, find their associations with prognostic factors of MM.

Methods: thirty patients with newly diagnosed and chemotherapy naïve active MM, along with 20 healthy participants of comparable age and sex were recruited, after diagnosis of $\mathrm{MM}$; blood samples were collected from both patients and controls for flow cytometric detection of CD4+, CD8+, CD4+PD1+, and CD8+PD1+ T cells, total MPs, CD138+ MPs, and platelet MPs.

Results: MM patients had statistically significant higher levels of TMPs, CD138+MPs compared to their controls, while PMPs exhibited no significant difference between both groups. Statistically significant higher percentages of $\mathrm{CD} 8+, \mathrm{PD} 1 \mathrm{CD} 8+, \mathrm{PD} 1 \mathrm{CD} 4+\mathrm{T}$ cells were detected in patients compared to controls, while the latter group had a significantly higher percentage of $C D 4+T$ cells than MM patients, patients who didn't achieve complete response, had significantly higher percentages of PMPs, CD138+MPs, PD1+CD8+, PD1+CD4+, and CD8+T cells (cutoff values $=61,10.6,13.5,11.3 \& 20.1$ respectively), ( $p$-values $=0.002,0.003,0.017,0.001 \& 0.008$ respectively).

Conclusion: Microparticles and PD1 expressions were associated with proliferative potential and resistance to Bortezomib-based treatments, our results suggested that they played a crucial role in myeloma progression.

\section{Introduction}

Multiple myeloma (MM), a type of malignancy arises from plasma cells in bone marrow, represents about $10 \%$ of all hematologic malignancies, standard approach of treatment consists of induction therapy followed by high dose chemotherapy and autologous stem cell transplantation (ASCT) in candidate patients, for non-candidate patients, standard doublet, triplet, or quadruplet, agent-containing induction treatment are applied until progression. Although MM is still considered as an incurable disease by current standards, the development of several combination therapies, and immunotherapy approaches has increased the hope towards transforming MM into an indolent, chronic disease, and possibly achieving a cure in some patients (1) with a median survival for all patients of about 3-4 years(2).

In addition to the International and Durie-Salmon staging systems, biological markers, including cytogenetic abnormalities such as presence of translocations including $t(4 ; 14)$, and $t(14 ; 16)$, hypodiploidy, del(17p), and del(13), serum $\beta 2$-microglobulin levels greater than $2.5 \mathrm{mg} / \mathrm{L}$, an elevated plasma cell labeling index, and detection of circulating plasma cells, are predictors of poor prognosis in newly diagnosed MM patients $(3,4)$.

Microparticles (MP) are membrane vesicles or extracellular vesicles shed systemically into the circulation, ranging in size from $0.1-1 \mu \mathrm{m}$ in diameter $(5,6)$. MPs rather, develop as a result of blebbing of plasma membrane (7), previous studies have reported that MPs provide a "non-genetic" basis for the acquirement, 
progression and supremacy of detrimental tumor behaviors, including enhanced metastatic potentiality of malignant cells and multidrug resistance $(\mathrm{MDR})(8,9)$.

CD138, a transmembrane heparin sulfate proteoglycan, is expressed on the surface of mature plasma cells to act as a classical co-receptor for growth factors, angiogenic factors, and chemokines; it is the gold standard marker for detecting MM cells using immunohistochemistry and multiparametric flow cytometry analysis of bone marrow biopsies (10).

Multiple myeloma is a tumor of elderly with longtime antigen exposure, and subsequent over-expression of PD 1 to indicate myeloma antigen-exposed $T$ cells, viral antigen-specific memory $T$ cells, or immune senescent cells(11), up-regulation of PD1 on CD8+, CD4 + T cells, and NK cells is observed in MM(12), blocking of PD1 will restore T and NK cell functions. PD-L1, a major ligand of PD1, is upregulated on myeloma cells to become more proliferative, resistant to cell-mediated killing and traditional myeloma drugs(13). Engagement of PD-1 by its ligands, PD-L1 or PD-L2, results in the activation of phosphatases that deactivate signals emanating from the Tcell receptor(14), up regulates the expression of basic leucine ATF-like transcription factor (BATF), which in turn impairs T-cell proliferation and cytokine secretion (15).

Preclinical data have confirmed the important role of the PD-1 pathway in immune evasion by MM cells (16), anti-PD1 and anti-PD-L1 monoclonal antibodies exhibited objective responses and antitumor activity in relapsed and refractory MM in phase I studies $(17,18)$.

We tried to shed light on the expression of PD1 and CD138 + microparticles in MM and their possible interplay as a mechanism of resistance to standardized treatments by proteasome inhibitors and immunomodulatory drugs, in addition, find their associations with other prognostic factors of MM.

\section{Patients And Methods}

The study was a prospective non randomized controlled one carried out in Assiut university hospital and south Egypt cancer Institute of Assiut University.

-Ethical statement

All methods were carried out in accordance with declarations of Helsinki, the study was approved by ethical committee of faculty of medicine, Assiut university (IRB no: 17300484). Written informed consents were obtained from all participants after explaining our objectives and study procedures.

-Inclusion and exclusion

A total of 30 patients with newly diagnosed chemotherapy naïve active multiple myeloma were recruited over a period of one year and followed up over a period of 6 months to determine their response to treatments, bisphosphonates and palliative local radiotherapy were allowed, patients with previous history of chemotherapy, targeting therapy, or hormonal therapy for any other malignancies were excluded, also patients with excruciated infections, and non-candidate patients for myeloma therapy were excluded. In addition, 19 healthy participants of comparable age and sex were recruited.

-Methodology 
After diagnosis of multiple myeloma by bone marrow aspirate \pm biopsy for evaluation of plasma cell infiltration, immunophenotyping, flow cytometry, protein electrophoresis, immunofixation electrophoresis, serum free light chain measurements (done in limited number of cases), blood samples were collected from both patients and controls for flow cytometric detection of CD4+T cells, CD8+T cells, CD4+PD1+ T cells, CD8+PD1+ T cells, total Microparticles (TMP), CD138+ MPs, and platelet MPs (PMP).

Patients were evaluated for different prognostic factors and hematologic parameters including, $C B C, \beta 2$ microglobulin, LDH, serum calcium, and blood chemistries (CRAB signs).

Evaluation of bone lysis was done based on whole body magnetic resonance imaging; any focal lesion to be considered of value must be $\geq 5 \mathrm{~mm}$ in size.

Patients with performance status $\leq 2$ received Bortezomib with dexamethasone or Bortezomib, lenalidomide, and dexamethasone regimens; monthly zoledronic acid was given \pm palliative local radiotherapy to alleviate pain. Other supportive measures including recombinant erythropoietin and darbepoitin alfa were used to treat myeloma-associated anemia to maintain $\mathrm{Hb}$ around $12 \mathrm{~g} / \mathrm{dL}$ and below $14 \mathrm{~g} / \mathrm{dL}$ to avoid thromboembolic complications after measuring their microparticles level, also granulocyte colony-stimulating factor (G-CSF) was used to treat chemotherapy-induced neutropenia.

Patients at high risk of thrombosis or had elevated levels of MPs received high dose of dexamethasone, also patients under lenalidomide treatment received aspirin to avoid thromboembolic complications.

Complete response (CR) was defined as negative immunofixation on the serum and urine, with disappearance of any soft tissue plasmacytomas and $\leq 5 \%$ plasma cells in $B M$, deviation from this definition of $C R$ was considered non CR.

\section{Flow cytometric detection of Microparticles}

Blood samples were collected into a $5 \mathrm{~mL}$ tubes containing $3.2 \%$ citrate for MPs isolation

\section{Microparticles Isolation and Characterization}

The MPs were isolated within $15 \mathrm{~min}$. after collection. Cells were removed by centrifugation for $20 \mathrm{~min}$ at 1550 $\times \mathrm{g}$ at $20^{\circ} \mathrm{C}$. Then $250 \mu \mathrm{L}$ of plasma were centrifuged for $30 \mathrm{~min}$ at $18,800 \times \mathrm{g}$ at $20^{\circ} \mathrm{C}$. After centrifugation, the supernatant was removed and the pellet was resuspended in phosphate-buffered saline (PBS) and centrifuged for $30 \mathrm{~min}$ at $18,800 \times \mathrm{g}$ at $20^{\circ} \mathrm{C}$. The supernatant was removed again and MPs pellet was suspended in PBS.

Flow cytometric analysis was used to quantify and characterize MPs. Five $\mu \mathrm{L}$ of MPs sample were diluted in 35 $\mu \mathrm{L}$ PBS containing $2.5 \mathrm{mM} \mathrm{CaCl}$. The samples were then incubated for $20 \mathrm{~min}$ at room temperature in the dark with $5 \mu \mathrm{L}$ of fluoroisothiocyanate (FITC)-conjugated annexin V (IQ products, Netherland), $5 \mu \mathrm{L}$ of phycoerythrin (PE) CD146, and allophycocyanin (APC) conjugated anti CD 45 (All from Becton Dickinson Biosciences, USA). 5 $\mu \mathrm{L}$ FITC-conjugated annexin V (IQ products, Netherland), $5 \mu \mathrm{L}$ of PE conjugated CD138 and peridiniumchlorophyll-protein (Per-CP) conjugated CD41 in separate tubes then PBS/calcium buffer were added and the samples were analyzed on a Fluorescence Activated Cell Sorter (FACS)Caliber flow cytometry with Cell Quest software (Becton Dickinson Biosciences, USA). Anti-human IgG was used as an isotype-matched negative control for each sample. Fifty thousand events were analyzed. 
Total MPs were identified on the basis of their forward scatter compared with that of calibrate reference beads of $1.0 \mu \mathrm{m}$ to calibrate the size range of microparticles (Latex beads, amine-modified polystyrene, fluorescent red aqueous suspension, $1.0 \mu \mathrm{m}$ mean particle size, Sigma-Aldrich ChemieGmbh Munich, Germany) and positivity for annexin V. Total MPs were reported as a percentage of the total events. MPs subpopulations were identified by their ability to bind cell-specific monoclonal antibodies. Platelet MPs was detected as CD41+ MPs. Myeloma MPs were CD138+MPs. The percentage platelet and myeloma MPs were expressed as percentage of total MPs (figure 1).

\section{Flow cytometric detection of T lymphocyte subsets in peripheral blood.}

T lymphocyte subsets in the peripheral blood were assessed by staining $50 \mu$ of blood sample with $5 \mu$ of the following monoclonal antibodies in separate tubes; Fluoroisothiocyanate (FITC)-conjugated-PD-1, phycoerythrin (PE)-conjugated-CD8, peridinium-chlorophyll-protein (Per-CP)-conjugated-CD4. All monoclonal antibodies were purchased from Becton Dickinson (BD) Biosciences, San Jose, CA, USA. After incubation for 20 minutes at $4^{\circ} \mathrm{C}$ in the dark, RBCs lysis was done and washing with phosphate buffer saline (PBS). The cells were resuspended in PBS and analyzed by FACSCalibur flow cytometry with Cell Quest software (BD Biosciences, USA). Human IgG was used as an isotype-matched negative control for each sample. Forward and side scatter histogram was used to define the lymphocyte populations. Then the expression of CD4, CD8 on the T lymphocytes was assessed to detect CD4+ (T-helper cells), CD8+ (T-cytotoxic cells). Then the expression of PD-1 was assesses on CD8+ and CD4+ cells to detect (PD1+CD4+T cells) and (PD1+CD8+T cells) (Figure2). The expression was reported as percentages of each cell population.

\section{Statistics}

It was expected that the percentage of MM in Egypt in 2020 according to Amal et al study (19) was $0.45 \%$ to total number of cancers, so the sample size was calculated based on the equation $=$, where $p=0.0045, q=0.995$, absolute error $\mathrm{e}=0.03$, and $\mathrm{z}$ for $99 \%$ confidence interval was. 2.56 , so the calculated sample size was 32 patients, and we recruited 30 patients for our study.

Data were analyzed using IBM SPSS version 26, descriptive statistics in the form of mean, median, standard error, standard deviation, and percentages, Shapiro-Wilk test and Q-Q plots were applied to detect normality of variables, and Cook's distance test was plotted against serial number of cases to determine the influential outliers as shown in figure (3), cases number $2,19, \& 26$ could affect our results and may be considered influential outliers and to confirm this effect, standardized DFFIT was applied and plotted against serial cases showing all cases were not deviated away from \pm 3 , so these values were not most probably influential.

Independent sample t-test and Mann Whitney $U$ test were applied for the associations between continuous and two-groups categorical variables, while one way Manova test was applied for detecting differences of multiple continuous variables on dependent categorical variable (ISS stage) after applying homogeneity test to insure equality of variances (Levene's test), and equality of covariances (Box's test), in addition post hoc analysis was applied using Tukey test for pairwise comparison, multicollinearity diagnostics was done with VIF $<4$, but the 
condition index $>10$ for all immune cells and Microparticles due to the presence of autocorrelations between these variables, so to determine which one of these variables greatly affect the variation of response Logistic regression with forward LR method was applied changing ISS stage into dummy variables. Roc curve was also applied for different variables to find their cutoff points of achieving non CR, all data were considered significant at $p$-value $<5 \%$.

\section{Results}

Thirty patients with MM and 19 healthy controls were enrolled in this study, with significant accumulations of TMPs $(p<0.0001)$, and CD138+MPs $(p<0.0001)$ in patients compared to controls, while no significant difference in PMPs $(p=0.07)$ among both groups, table (1).

Table 1: Differences of microparticles between patients and controls

\begin{tabular}{|llll|}
\hline & patients & controls & $p$-value \\
\hline TMPs & $68.95 \pm 1.4$ & $54.86 \pm 0.5$ & 0.0001 \\
\hline PMPs & $63.18 \pm 2.1$ & $56.79 \pm 2.8$ & 0.07 \\
\hline CD138+MPs & $11.75 \pm 0.4$ & $4.75 \pm 0.2$ & 0.0001 \\
\hline
\end{tabular}

TMPs; total microparticles, PMPs; platelet microparticles, data expressed as mean \pm SE, independent sample ttest, and Mann Whitney U test for significance, $p<0.05$.

Furthermore, patients with MM showed statistically significant higher percentages of CD8+T cells $(p=0.007)$, PD1+CD8+T cells $(p<0.0001)$, and PD1+CD4+T cells $(p<0.0001)$ compared to their controls, while healthy controls had a significantly higher CD4+T cells $(p<0.0001)$ than patients as shown in table 2.

Table 2: differential accumulation of T lymphocytes and PD 1 expressing $\mathrm{T}$ lymphocytes among study groups.

\begin{tabular}{|llll|}
\hline & Patients & Controls & $p$-value \\
\hline CD8+T cells & $21.2 \pm 0.66$ & $18.1 \pm 0.9$ & 0.007 \\
\hline CD4+T cells & $43.1 \pm 1.3$ & $49.8 \pm 0.5$ & 0.0001 \\
\hline PD1+CD8+T cells & $14.26 \pm 0.5$ & $7.5 \pm 0.3$ & 0.0001 \\
\hline PD1+CD4+T cells & $12.7 \pm 0.4$ & $8.3 \pm 0.6$ & 0.0001 \\
\hline
\end{tabular}

Data expressed as mean $\pm S E$, independent sample t-test and Mann Whitney $U$ test for significance, $p<0.05$

Among 30 patients with active multiple myeloma, 7, 17, and 6 patients were in stages I, II, \& III respectively, with 11 patients achieved complete response to Bortezomib based combinations while 19 patients didn't achieve CR as illustrated in table 3

Table 3: Characteristics of $30 \mathrm{MM}$ patients 


\begin{tabular}{|c|c|}
\hline Factor & Mean \pm SE \\
\hline $\mathrm{Hb}(\mathrm{g} / \mathrm{dL})$ & $9.25 \pm 0.3$ \\
\hline Platelets & $130.8 \pm 9.2$ \\
\hline $\mathrm{LDH}(\mathrm{U} / \mathrm{L})$ & $932.7 \pm 65.6$ \\
\hline serum calcium (mg/dL) & $11.7 \pm 0.3$ \\
\hline Total protein (g/L) & $69.9 \pm 1.0$ \\
\hline Serum albumin $(\mathrm{g} / \mathrm{L})$ & $30.5 \pm 1.6$ \\
\hline M protein (g/L) & $43.5 \pm 2.3$ \\
\hline Urea (mg/dL) & $45.1 \pm 2.6$ \\
\hline Creatinine (mg/dL) & $1.9 \pm 0.2$ \\
\hline Bone marrow plasma & $41.8 \pm 3.0$ \\
\hline Lytic bony lesions & $\begin{array}{l}\leq 1=8 \text { patients } \\
>1=22 \text { patients }\end{array}$ \\
\hline$\beta 2 \mathrm{M}(\mathrm{mg} / \mathrm{mL})$ & $4.4 \pm 0.4$ \\
\hline \multicolumn{2}{|l|}{ ISS staging } \\
\hline stage I & $7(23.3 \%)$ \\
\hline stage II & $17(56.7 \%)$ \\
\hline stage III & $6(20 \%)$ \\
\hline \multicolumn{2}{|l|}{ Response } \\
\hline $\mathrm{CR}$ & $11 / 30$ \\
\hline non $\mathrm{CR}$ & $19 / 30$ \\
\hline
\end{tabular}

LDH; lactate dehydrogenase, $\mathrm{Hb}$; hemoglobin, MM; multiple myeloma, $\beta 2 \mathrm{M}$; beta2 microglobulin, ISS; international staging system, CR; complete response.

Table 4 described different correlations between MPs, immune cells, and prognostic factors, with positive correlations were reported between PMP and PD1+CD4+T cells, CD138+MPs and CD8+T cells, PD1+CD8+T cells and PD1+CD4+T cells, PD1+CD8+T cells were positively correlated with LDH, M-protein, bone marrow plasma percentage, and $\beta 2$ microglobulin, and $\beta 2$ microglobulin was also correlated with PD1+CD4+T cells.

Table 4: Correlations between MPs, PD1, and other prognostic factors of MM 


\begin{tabular}{|c|c|c|c|c|c|c|c|c|}
\hline & & TMPs & PMP & CD138+MP & PD1+CD8+ & PD1+CD4+ & CD8+ & CD4+ \\
\hline \multirow[t]{2}{*}{ TMPs } & $\mathbf{r}$ & NA & .252 & .149 & $-.120-$ & .149 & +.547 & -.466 \\
\hline & $p$ & & .179 & .432 & .526 & .432 & .002 & .009 \\
\hline \multirow[t]{2}{*}{ PMP } & $r$ & .252 & NA & .295 & .248 & +.496 & .254 & .123 \\
\hline & $p$ & .179 & & .113 & .187 & .005 & .175 & .516 \\
\hline \multirow[t]{2}{*}{ CD138+MP } & $r$ & .149 & .295 & NA & $-.032-$ & .229 & +.514 & .113 \\
\hline & $p$ & .432 & .113 & & .868 & .224 & .004 & .551 \\
\hline \multirow[t]{2}{*}{ PD1+CD8+ } & $r$ & $-.120-$ & .248 & $-.032-$ & NA & +.457 & .112 & .332 \\
\hline & $p$ & .526 & .187 & .868 & & .011 & .557 & .073 \\
\hline \multirow[t]{2}{*}{ PD1+CD4+ } & $\mathbf{r}$ & .149 & +.496 & .229 & +.457 & NA & .306 & -.026 \\
\hline & $p$ & .432 & .005 & .224 & .011 & & .100 & .893 \\
\hline \multirow[t]{2}{*}{ CD8 } & $\mathbf{r}$ & +.547 & .254 & +.514 & .112 & .306 & NA & -.215 \\
\hline & $p$ & .002 & .175 & .004 & .557 & .100 & & .254 \\
\hline \multirow[t]{2}{*}{ CD4 } & $r$ & -.466 & .123 & .113 & .332 & $-.026-$ & -.215 & NA \\
\hline & $p$ & .009 & .516 & .551 & .073 & .893 & .254 & \\
\hline \multirow[t]{2}{*}{ LDH } & $r$ & $-.161-$ & .099 & .120 & +.609 & .153 & .227 & .088 \\
\hline & $p$ & .395 & .602 & .527 & .000 & .420 & .227 & .645 \\
\hline \multirow[t]{2}{*}{ serum calcium } & $\mathbf{r}$ & .165 & .282 & .027 & .319 & .183 & .150 & .049 \\
\hline & $\mathrm{p}$ & .384 & .131 & .887 & .085 & .333 & .430 & .795 \\
\hline \multirow[t]{2}{*}{ serum albumin } & $\mathbf{r}$ & $-.198-$ & -.252 & -.204 & -.296 & -.190 & -.191 & .214 \\
\hline & $\mathbf{p}$ & .294 & .180 & .279 & .112 & .316 & .311 & .255 \\
\hline \multirow[t]{2}{*}{ M protein } & $\mathbf{r}$ & $-.130-$ & .188 & .048 & +.703 & .160 & .306 & .234 \\
\hline & $\mathrm{p}$ & .494 & .320 & .801 & .000 & .399 & .100 & .214 \\
\hline \multirow[t]{2}{*}{ creatinine } & $\mathbf{r}$ & -.068 & .026 & .227 & .273 & .200 & .257 & -.154 \\
\hline & $\mathrm{p}$ & .721 & .890 & .228 & .144 & .288 & .170 & .416 \\
\hline \multirow[t]{2}{*}{ bone marrow plasma } & $\mathbf{r}$ & $-.150-$ & .158 & .314 & +.559 & .353 & .097 & .114 \\
\hline & $\mathrm{p}$ & .429 & .404 & .091 & .001 & .056 & .609 & .548 \\
\hline \multirow[t]{2}{*}{$\beta 2 M$} & $\mathbf{r}$ & $-.146-$ & .304 & .165 & +.839 & +.450 & .081 & .349 \\
\hline & $\mathbf{p}$ & .441 & .102 & .384 & .000 & .013 & .672 & .059 \\
\hline \multirow[t]{2}{*}{ total protein } & $\mathbf{r}$ & .353 & -.111 & -.157 & -.057 & .242 & .255 & -.429 \\
\hline & $\mathrm{p}$ & .056 & .560 & .406 & .764 & .198 & .175 & .018 \\
\hline
\end{tabular}


r; Pearson correlation, p; p-value, MP; microparticles, $\beta 2 \mathrm{M}$; beta2 microglobulin.

As shown in table 5 , and figures $(4,5, \& 6)$, patients with CR had significantly lower PMP, CD138+MP, PD1+CD8+T cells, PD1+CD4+T cells, and CD8+T cells compared with patients without $C R$, while no significant difference in TMP and CD4+T cells between response groups.

Table 5: impact of MPs and PD1 expressing lymphocytes on the response of 30 patients with MM

\begin{tabular}{|c|c|c|c|}
\hline & response & Mean \pm SE & $p$-value \\
\hline \multirow[t]{2}{*}{ TMPs } & $\mathrm{CR}$ & $67.6 \pm 2.5$ & 0.61 \\
\hline & non CR & $69.7 \pm 1.6$ & \\
\hline \multirow[t]{2}{*}{ PMP } & CR & $54.4 \pm 3.1$ & 0.002 \\
\hline & non CR & $68.3 \pm 2.1$ & \\
\hline \multirow[t]{2}{*}{ CD138.MP } & $\mathrm{CR}$ & $10.3 \pm 0.5$ & 0.001 \\
\hline & non CR & $12.7 \pm 0.4$ & \\
\hline \multirow[t]{2}{*}{ PD1+CD8+T } & CR & $12.7 \pm 0.5$ & 0.01 \\
\hline & non CR & $15.2 \pm 0.6$ & \\
\hline \multirow[t]{2}{*}{$\mathrm{PD} 1+\mathrm{CD} 4+\mathrm{T}$} & $\mathrm{CR}$ & $10.9 \pm 0.4$ & 0.0001 \\
\hline & non CR & $13.7 \pm 0.5$ & \\
\hline \multirow[t]{2}{*}{$\mathrm{CD} 8+\mathrm{T}$} & $\mathrm{CR}$ & $19.0 \pm 1.1$ & 0.01 \\
\hline & non CR & $22.4 \pm 0.7$ & \\
\hline \multirow[t]{2}{*}{$\mathrm{CD} 4+\mathrm{T}$} & $\mathrm{CR}$ & $42.1 \pm 2.2$ & 0.52 \\
\hline & non CR & $43.7 \pm 1.6$ & \\
\hline
\end{tabular}

TMP; total microparticles, PMP; platelet microparticles, CR; complete response, PD1; programmed death-1, Mann Whitney test was applied for TMP, PMP, PD1+CD4+T, and CD4 and independent sample t-test was applied for the remaining variables.

Receiver Operating Characteristic (ROC) curve analysis has shown that among different MPs and immune cells, PMP, CD138+MP, PD1+CD8+T cells, PD1+CD4+T cells, and CD8+T have shown good accuracy in predicting the response to Bortezomib based combination in patients with $\mathrm{MM}$ as illustrated in table 6, and figure 7, the largest AUC was observed with PD1+CD4+T cells for predicting non CR among active myeloma patients (AUC=0.94, $p=0.0001)$ with the highest sensitivity (92\%), specificity (80\%), and performance $(72 \%)$.

Table 6: performance of different MPs and immune cells in MM 


\begin{tabular}{|lllllll|}
\hline Variable & AUC & Cut off & Sensitivity & Specificity & Youden index & $p$-value \\
\hline PMP & & & & & & \\
\hline CD138 +MP & 0.84 & $\geq 61$ & 83 & 74 & 57 & $\mathbf{0 . 0 0 2}$ \\
\hline PD1+CD8+T cells & 0.73 & $\geq 10.6$ & 91 & 74 & 65 & $\mathbf{0 . 0 0 3}$ \\
\hline PD1+CD4+T cells & 0.94 & $\geq 13.5$ & 71 & 75 & 46 & $\mathbf{0 . 0 1 7}$ \\
\hline CD8+T cells & 0.79 & $\geq 20.1$ & 83 & 70 & 53 & $\mathbf{0 . 0 0 0 1}$ \\
\hline
\end{tabular}

AUC; area under the curve, PMP; platelet Microparticles, MP; Microparticles, PD1; programmed death-1

\section{Differences of MPs and immune cells across ISS stages}

One way Manova with Tukey test was applied after performing Levene's test of homogeneity to assess equality of variance for CD138+MP, CD8, PD1+CD8+T cells $(p=0.3,0.4,0.2)$, and Box's test to assess equality of dependent covariance across all stages $(p=0.316)$, generally there was a significant effect of all three variables together on ISS stage (Wilks' Lambda $p$-value=0.009); no significant differences were detected for CD138+MP $(p=0.6)$ and CD8 $(p=0.5)$, there was significant differences in PD1+CD8+T cells across different stages $(p=0.001)$, table (7), figure (8). Independent sample Kruskal Wallis test was applied for other Microparticles and immune cells; no significant differences of the distributions of TMP, PMP, and CD4+T cells across different stages of MM patients ( $p=0.8,0.6,0.07$ respectively), however significant difference in the distribution of PD1+CD4+T across ISS stages was detected ( $p=0.041)$ as shown in figure (9).

Table (7): multivariate analysis of normally distributed variables on ISS stage

\begin{tabular}{|llllll|}
\hline Factor & Dependent & F-statistics & $\mathrm{df}$ & $\mathrm{R}^{2}$ & $p$-value \\
\hline \multirow{5}{*}{ ISS stage } & CD138MP & 0.428 & 2 & 0.34 & 0.6 \\
& PD1+CD8+T & 9.467 & 2 & 0.412 & 0.001 \\
& CD8+T cells & 0.524 & 2 & 0.037 & 0.5 \\
\hline
\end{tabular}

df; degrees of freedom, ISS; international staging system, PD1; programmed death-1, one way Manova for significance, $p<0.05$

\section{Logistic regression}

Due to autocorrelations between MPs and immune cells, logistic regression with forward LR method was carried out, the overall prediction rate of the model for response to treatment was $90 \%$ as shown in table (8a), for each point of increase in PD1+CD4+T cells there was a decrease in the odds of CR by $15.5 \%, p=0.025$, also for each point of increase in CD138+MP there was a decrease in the odds of CR by $47.2 \%, p=0.059$, table (8b), 
furthermore other variables were removed from the model because of autocorrelation and no added value in the prediction rate of model.

Table (8a): model summary of logistic regression done for 30 patients with MM

\begin{tabular}{|lllllll|}
\hline $\begin{array}{l}\text { Independent } \\
\text { variables }\end{array}$ & $\begin{array}{l}\text { Dependent } \\
\text { variables }\end{array}$ & $\mathrm{R}^{2}$ & Chi $^{2}$ & $p$-value & $\mathrm{df}$ & $\begin{array}{l}\text { \% of correct } \\
\text { classification }\end{array}$ \\
TMP & Response & Step1 & 19.487 & $<0.0001$ & 1 & $\begin{array}{l}\text { Step 1 }= \\
\text { PMP }\end{array}$ \\
CD138MP & & 0.653 & & & & $83.3 \%$ \\
PD1CD8 & & Step 2 & 5.509 & $=0.019$ & 1 & Step 2= \\
PD1CD4 & & 0.77 & & & & $90 \%$ \\
CD4 & & & & & & \\
CD8 & & & & & & \\
\hline
\end{tabular}

Response is a binary variable with two categories; 0 ; non $\mathrm{CR}, 1$; CR, df; degrees of freedom, $p<0.05$

\begin{tabular}{|c|c|c|c|c|c|c|c|c|c|}
\hline & & \multirow[t]{2}{*}{$B$} & \multirow[t]{2}{*}{ S.E. } & \multirow[t]{2}{*}{ Wald } & \multirow[t]{2}{*}{$\mathrm{df}$} & \multirow[t]{2}{*}{$\begin{array}{l}p \text { - } \\
\text { value }\end{array}$} & \multirow[t]{2}{*}{$\operatorname{Exp}(B)$} & \multicolumn{2}{|c|}{$\begin{array}{l}95 \% \text { C.I. for } \\
\operatorname{Exp(B)}\end{array}$} \\
\hline & & & & & & & & Lower & Upper \\
\hline \multirow{2}{*}{$\begin{array}{l}\text { Step } \\
1^{\text {a }}\end{array}$} & $\mathrm{PD} 1+\mathrm{CD} 4+\mathrm{T}$ & $-1.790-$ & .654 & 7.500 & 1 & .006 & .167 & .046 & .601 \\
\hline & Constant & 21.361 & 7.997 & 7.135 & 1 & .008 & 1891728042.290 & & \\
\hline \multirow{3}{*}{$\begin{array}{l}\text { Step } \\
2^{\mathrm{b}}\end{array}$} & $\mathrm{CD} 138+. \mathrm{MP}$ & $-.751-$ & .398 & 3.553 & 1 & .059 & .472 & .216 & 1.030 \\
\hline & $\mathrm{PD} 1+\mathrm{CD} 4+\mathrm{T}$ & $-1.864-$ & .834 & 5.001 & 1 & .025 & .155 & .030 & .794 \\
\hline & Constant & 30.621 & 12.083 & 6.423 & 1 & .011 & 19892982541237.910 & & \\
\hline
\end{tabular}

\section{Discussion}

Multiple myeloma is a genetically heterogeneous clonal plasma cell disease which is substantially preceded by an asymptomatic premalignant stage, monoclonal gammopathy of undetermined significance (MGUS), to clinically aggressive stage with overt clinical pictures (20). Among all cancers, it represents about $1 \%$, in spite, a minority of them achieved sustained complete response for a prolonged period or the so-called operational cure (21), even if they achieve this cure they will continue on suppressive therapy to fight against the risk of relapse with no clear plateau in overall survival (22). 
Our results elucidated significant higher levels of TMP, CD138+MP, T cell subsets, PD1 expressed on T cells in MM patients compared with controls, also there were significant positive correlations between PMP and PD1+CD4+T cells, CD138+MP and CD8, and PD1+CD8+T cells and all of the followings LDH, M protein, BM plasma level, and $\beta 2$ microglobulin, furthermore, there were significantly elevated levels of PMP, CD138MP, PD1, CD8+T cells in patients who didn't achieve CR with specific cutoff values as mentioned in table 6.

Immune checkpoint blockade is proposed to be effective in many cancers where immune deregulation due to increased expression of negative co-stimulation of cells in tumor microenvironment plays important role in tumor progression and resistance to treatment, multiple myeloma is an example of these cancers with progressive immune dysregulation characterized by loss of myeloma reactive T-cell population, decreased antigen presenting and effector cell functions, and BM microenvironment that promotes immune escape $(23,24)$.

Batorov et al reported significantly higher levels of PD1+CD4+T cells, PD1+CD8+T cells, CD4+T cells, and CD8+T cells in multiple myeloma patients compared to healthy donors (25), On the contrary, Sponaas et al didn't detect any difference of PD1 expressed on CD8+T cells between myeloma patients and healthy controls, furthermore, high expression of PD1+CD8+T cells was not found to correlate with tumor load to suggest that these cells were specific for non-myeloma antigens (26), our results came in alignment with Batorov et al with exception of CD4+ which was higher in healthy controls compared to patients.

Physiologically, MPs take part in cell signaling and swapping of proteins and nucleic acids between cells, also are involved in the intercellular crosstalk, elevated levels of MPs are detected in many pathological conditions including inflammation, vascular diseases, diabetes, and cancers where they act as a surrogate marker for disease activity especially in poorly accessible tissues (27-30), it is well documented that immunomodulatory drugs play important role in treatment of $\mathrm{MM}$ to be involved in many treatment regimens, however the risk of thromboembolism increased with their use to focus on the clinical significance of MP especially PMP (29).

Studies reported that TMP, PMP, and CD138+MP were elevated in patients with MM compared to healthy controls with significant prognostic potential of CD138+MPs in predicting the response to treatment and risk of relapse (31), our results agreed with the previous study.

Our results showed no significant differences in the total MP among response groups to demonstrate that they may predict the disease state of MM patients compared to healthy controls rather than response state.

Resistance to chemotherapy and immunotherapy is characteristic of MM (32); furthermore myeloma and plasma cells remain restricted to bone marrow secreting abnormal immunoglobulins till advanced stage, therefore continued monitoring of response based on BM examination, protein electrophoresis, free light chain assay immunofixation, and whole body MRI is time consuming and limited especially in non-secretory MM, hence the need for a marker of high sensitivity and specificity for detecting early relapse is important. For that, MPs emerged as a surrogate marker for response in many cancers including $M M(33,34)$, our results failed to consider MPs as a marker for disease progression because of absence of significant differences of MPs across different ISS stages, in spite this study adds to this body of research and provides support for the use of MPs as a novel prognostic for response assessment in MM.

Crosstalk between tumor cells and immune cells in tumor microenvironment is critical for tumor progression; in addition, tumor cells are capable to hijack immune cells especially innate immunity, subsequently MPs released 
from tumor cells, not only contain messenger molecules, enzymes, RNAs, and even DNA, but also are capable of transferring these bioactive molecules from one cell to another, subsequently act as a vector for transferring messages between tumor cells and possibly immune cells to acquire aggressive phenotype(35, 36). This crosstalk rather appeared in the current study where significant positive correlations between TMP and CD8+T cells, PMP and PD1+CD4+T cells, and CD138+MP and CD8+T cells while negative correlation between TMP and CD8+T cells.

To our knowledge, this study was the first one to address the relations between Microparticles and immune cells and the added impact of these relations in resistance to treatment and disease progression, further studies with thorough methodology and adequate sample size may augment these relations.

\section{Conclusion}

We have demonstrated elevated levels of MPs and immune cells in MM patients compared to healthy controls, also the levels of these cells and particles were lower in patients achieved CR compared to those without CR, Microparticles and PD1 expressions were associated with proliferative potential and resistance to Bortezomibbased treatments, our results suggested that they played a crucial role in myeloma progression, in addition this study provides support for the potential prognostic value of MPs and the possible interplay between MPs and PD1 in multiple myeloma.

\section{Declarations}

Conflict of interest: the authors declared that they had no conflict of interest

Data availability statement: all data generated or analyzed during this study are included in this submitted article.

\section{References}

1. Köhler M, Greil C, Hudecek M, Lonial S, Raje N, Wäsch R, et al. Current developments in immunotherapy in the treatment of multiple myeloma. Cancer. 2018;124(10):2075-85.

2. Glavey SV, Ghobrial IM. American Society of Hematology Annual Meeting 2014: highlights in multiple myeloma. Expert review of hematology. 2015;8(3):273-5.

3. Avet-Loiseau H, Attal M, Moreau P, Charbonnel C, Garban Fdr, Hulin C, et al. Genetic abnormalities and survival in multiple myeloma: the experience of the Intergroupe Francophone du Myelome. Blood. 2007;109(8):3489-95.

4. Avet-Loiseau H, Soulier J, Fermand J, Yakoub-Agha I, Attal M, Hulin C, et al. Impact of high-risk cytogenetics and prior therapy on outcomes in patients with advanced relapsed or refractory multiple myeloma treated with lenalidomide plus dexamethasone. Leukemia. 2010;24(3):623-8.

5. Sink KM, Leng X, Williamson J, Kritchevsky SB, Yaffe K, Kuller L, et al. Angiotensin-converting enzyme inhibitors and cognitive decline in older adults with hypertension: results from the Cardiovascular Health Study. Archives of internal medicine. 2009;169(13):1195-202. 
6. Gong J, Jaiswal R, Mathys JM, Combes V, Grau GE, Bebawy M. Microparticles and their emerging role in cancer multidrug resistance. Cancer treatment reviews. 2012;38(3):226-34.

7. Jaiswal R, Raymond Grau GE, Bebawy M. Cellular communication via microparticles: role in transfer of multidrug resistance in cancer. Future oncology (London, England). 2014;10(4):655-69.

8. Gong J, Luk F, Jaiswal R, Bebawy M. Microparticles Mediate the Intercellular Regulation of microRNA-503 and Proline-Rich Tyrosine Kinase 2 to Alter the Migration and Invasion Capacity of Breast Cancer Cells. Frontiers in oncology. 2014;4:220.

9. Lu JF, Luk F, Gong J, Jaiswal R, Grau GE, Bebawy M. Microparticles mediate MRP1 intercellular transfer and the re-templating of intrinsic resistance pathways. Pharmacological research. 2013;76:77-83.

10. Rawstron AC, Orfao A, Beksac M, Bezdickova L, Brooimans RA, Bumbea H, et al. Report of the European Myeloma Network on multiparametric flow cytometry in multiple myeloma and related disorders. Haematologica. 2008;93(3):431-8.

11. Sponaas A-M, Yang R, Rustad EH, Standal T, Thoresen AS, Vo CD, et al. PD1 is expressed on exhausted T cells as well as virus specific memory CD8+ T cells in the bone marrow of myeloma patients. Oncotarget. 2018;9(62):32024.

12. Chung DJ, Pronschinske KB, Shyer JA, Sharma S, Leung S, Curran SA, et al. T-cell exhaustion in multiple myeloma relapse after autotransplant: optimal timing of immunotherapy. Cancer immunology research. 2016;4(1):61-71.

13. Ishibashi M, Tamura H, Sunakawa M, Kondo-Onodera A, Okuyama N, Hamada Y, et al. Myeloma drug resistance induced by binding of myeloma B7-H1 (PD-L1) to PD-1. Cancer immunology research. 2016;4(9):779-88.

14. Riley JL. PD-1 signaling in primary T cells. Immunological reviews. 2009;229(1):114-25.

15. Quigley M, Pereyra F, Nilsson B, Porichis F, Fonseca C, Eichbaum Q, et al. Transcriptional analysis of HIVspecific CD8+ T cells shows that PD-1 inhibits T cell function by upregulating BATF. Nature medicine. 2010;16(10):1147-51.

16. Atanackovic D, Luetkens T, Kröger N. Coinhibitory molecule PD-1 as a potential target for the immunotherapy of multiple myeloma. Leukemia. 2014;28(5):993-1000.

17. Ribas A, Hodi FS, Kefford R, Hamid O, Daud A, Wolchok JD, et al. Efficacy and safety of the anti-PD-1 monoclonal antibody MK-3475 in 411 patients (pts) with melanoma (MEL). American Society of Clinical Oncology; 2014.

18. Brahmer JR, Tykodi SS, Chow LQ, Hwu W-J, Topalian SL, Hwu P, et al. Safety and activity of anti-PD-L1 antibody in patients with advanced cancer. New England Journal of Medicine. 2012;366(26):2455-65.

19. Ibrahim AS, Khaled HM, Mikhail NNH, Baraka H, Kamel H. Cancer Incidence in Egypt: Results of the National Population-Based Cancer Registry Program. Journal of Cancer Epidemiology. 2014;2014:437971.

20. Rajkumar SV, Dimopoulos MA, Palumbo A, Blade J, Merlini G, Mateos MV, et al. International Myeloma Working Group updated criteria for the diagnosis of multiple myeloma. The Lancet Oncology. 2014;15(12):e538-48.

21. Tricot G, Spencer T, Sawyer J, Spoon D, Desikan R, Fassas A, et al. Predicting long-term ( $>$ or $=5$ years) eventfree survival in multiple myeloma patients following planned tandem autotransplants. British journal of haematology. 2002;116(1):211-7. 
22. Ravi P, Kumar SK, Cerhan JR, Maurer MJ, Dingli D, Ansell SM, et al. Defining cure in multiple myeloma: a comparative study of outcomes of young individuals with myeloma and curable hematologic malignancies. Blood Cancer Journal. 2018;8(3):26.

23. Rosenblatt J, Bar-Natan M, Munshi NC, Avigan DE. Immunotherapy for multiple myeloma. Expert review of hematology. 2014;7(1):91-6.

24. Dosani T, Carlsten M, Maric I, Landgren O. The cellular immune system in myelomagenesis: NK cells and T cells in the development of MM and their uses in immunotherapies. Blood Cancer J. 2015;5(7):e321.

25. Batorov EV, Aristova TA, Sergeevicheva VV, Sizikova SA, Ushakova GY, Pronkina NV, et al. Quantitative and functional characteristics of circulating and bone marrow PD-1- and TIM-3-positive T cells in treated multiple myeloma patients. Scientific Reports. 2020;10(1):20846.

26. Sponaas AM, Yang R, Rustad EH, Standal T, Thoresen AS, Dao Vo C, et al. PD1 is expressed on exhausted T cells as well as virus specific memory CD8+ T cells in the bone marrow of myeloma patients. Oncotarget. 2018;9(62):32024-35.

27. Bebawy M, Combes V, Lee E, Jaiswal R, Gong J, Bonhoure A, et al. Membrane microparticles mediate transfer of P-glycoprotein to drug sensitive cancer cells. Leukemia. 2009;23(9):1643-9.

28. Erdbruegger U, Grossheim M, Hertel B, Wyss K, Kirsch T, Woywodt A, et al. Diagnostic role of endothelial microparticles in vasculitis. Rheumatology (Oxford, England). 2008;47(12):1820-5.

29. Coppola A, Tufano A, Di Capua M, Franchini M. Bleeding and thrombosis in multiple myeloma and related plasma cell disorders. Seminars in thrombosis and hemostasis. 2011;37(8):929-45.

30. Simak J, Gelderman MP. Cell membrane microparticles in blood and blood products: potentially pathogenic agents and diagnostic markers. Transfusion medicine reviews. 2006;20(1):1-26.

31. Krishnan SR, Luk F, Brown RD, Suen H, Kwan Y, Bebawy M. Isolation of Human CD138(+) Microparticles from the Plasma of Patients with Multiple Myeloma. Neoplasia. 2016;18(1):25-32.

32. Lonial S, Mitsiades CS, Richardson PG. Treatment options for relapsed and refractory multiple myeloma. Clinical cancer research : an official journal of the American Association for Cancer Research. 2011;17(6):1264-77.

33. Benameur T, Chappard D, Fioleau E, Andriantsitohaina R, Martinez MC, Clere N, et al. Plasma cells release membrane microparticles in a mouse model of multiple myeloma. Micron (Oxford, England : 1993). 2013;5455:75-81.

34. Dimopoulos MA, Terpos E. Multiple myeloma. Annals of oncology : official journal of the European Society for Medical Oncology. 2010;21 Suppl 7:vii143-50.

35. Ratajczak J, Wysoczynski M, Hayek F, Janowska-Wieczorek A, Ratajczak MZ. Membrane-derived microvesicles: important and underappreciated mediators of cell-to-cell communication. Leukemia. 2006;20(9):1487-95.

36. Mause SF, Weber CJCr. Microparticles: protagonists of a novel communication network for intercellular information exchange. 2010;107(9):1047-57.

\section{Figures}



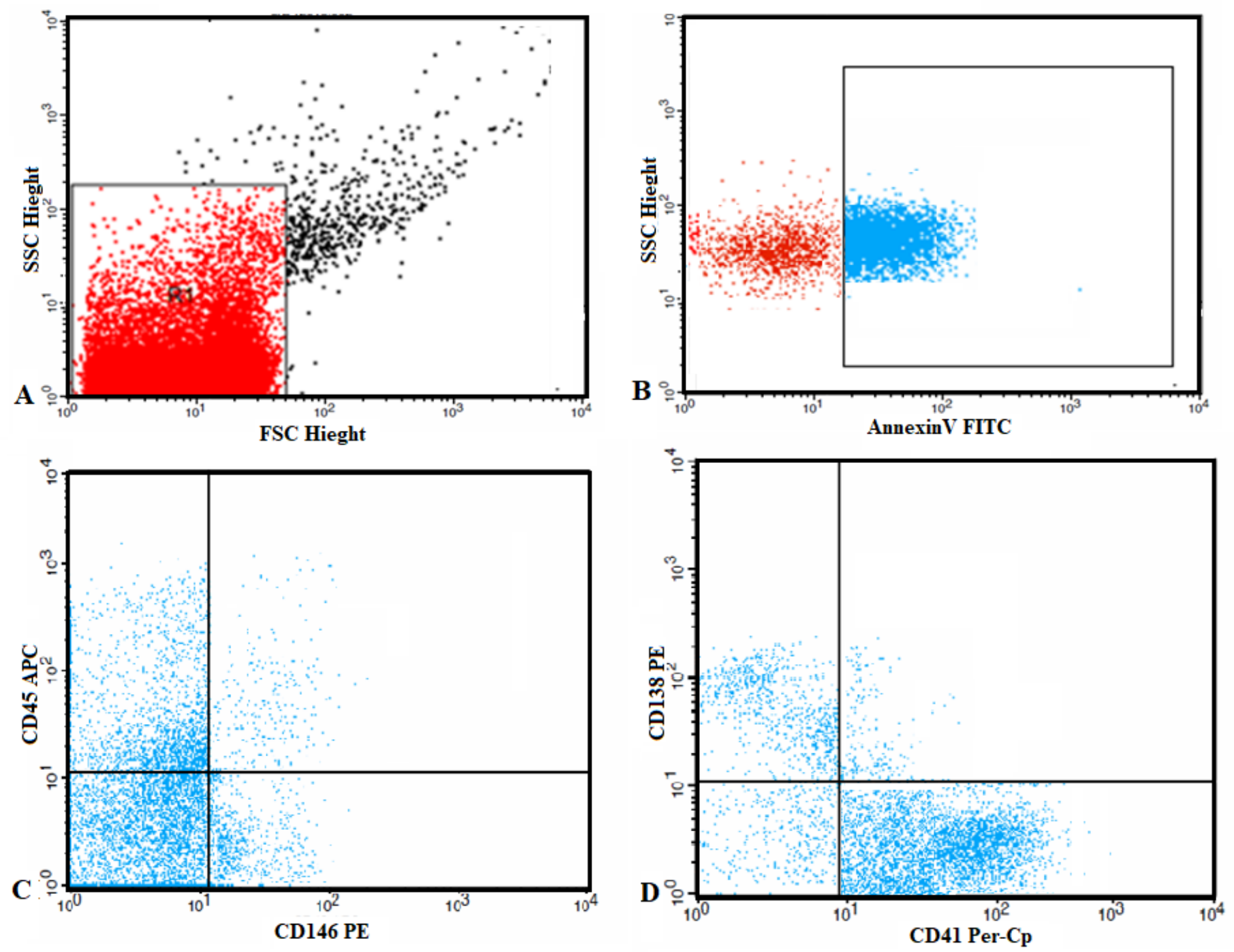

\section{Figure 1}

Flow cytometric analysis of circulating microparticles: A: Forward and side scatter histogram was used to define the microparticles (MPs) according to their size (R1). B: Events defined as MPs (R1) were then selected for their annexin V binding C, D: Then annexin V-positive MPs (total MPs) were further examined for expression of cell specific antibodies as CD45, CD146, CD41 and CD138 antibodies to detect endothelial, platelet and myeloma (CD138+ MPs). 

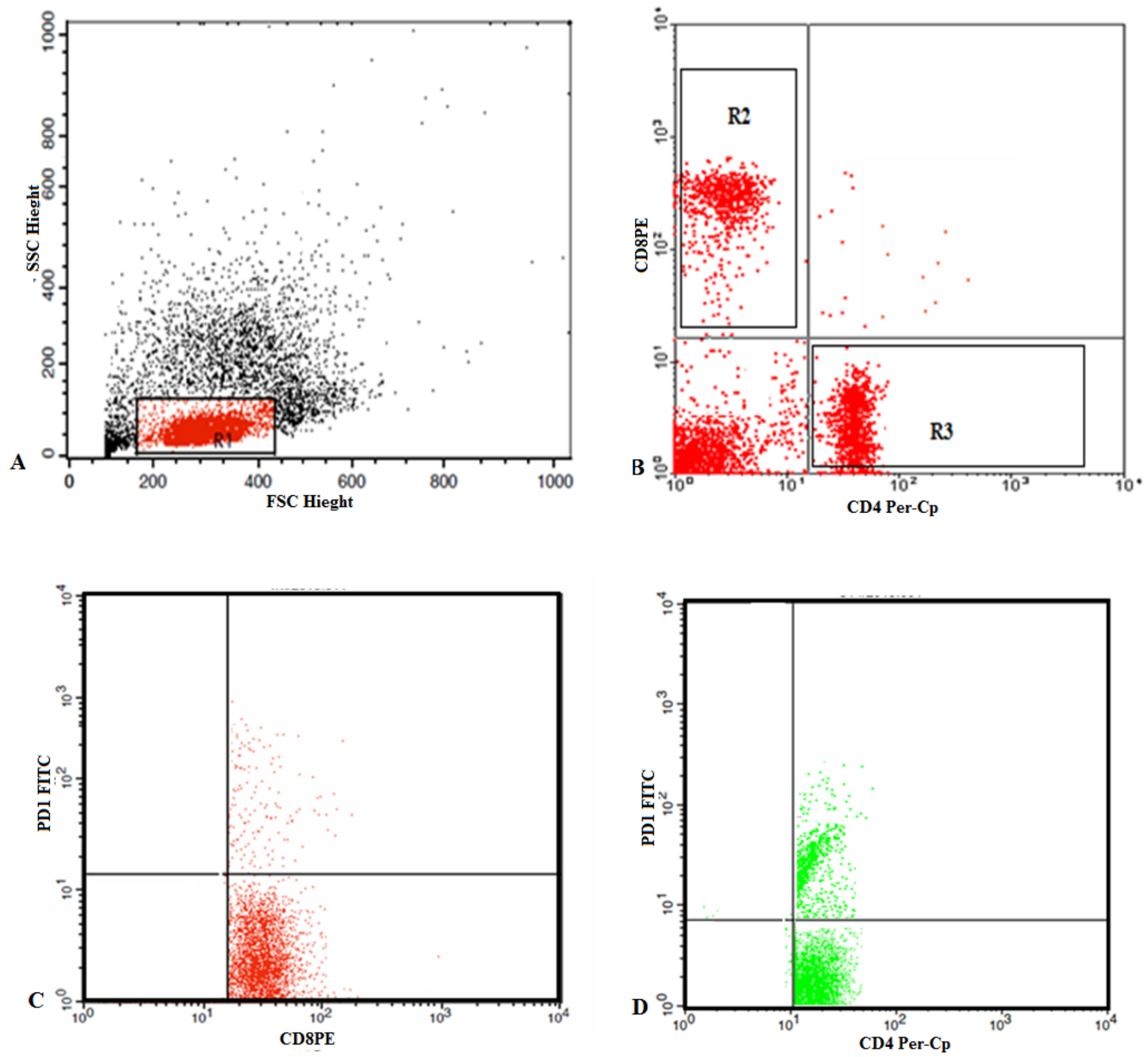

Figure 2

Flow cytometric detection of T lymphocyte subsets and their expression of PD-1 in peripheral blood of multiple myeloma. A: Forward and side scatter histogram was used to define the lymphocytes population. B: The expression of CD4, CD8 on the T lymphocytes was assessed to detected CD4+ (T-helper cells), CD8+ (T-cytotoxic cells). C, D: The expression of PD-1 was assesses on CD8+ and CD4+ cells to detect PD1+CD8+T cells and PD1+CD4+T cells. 


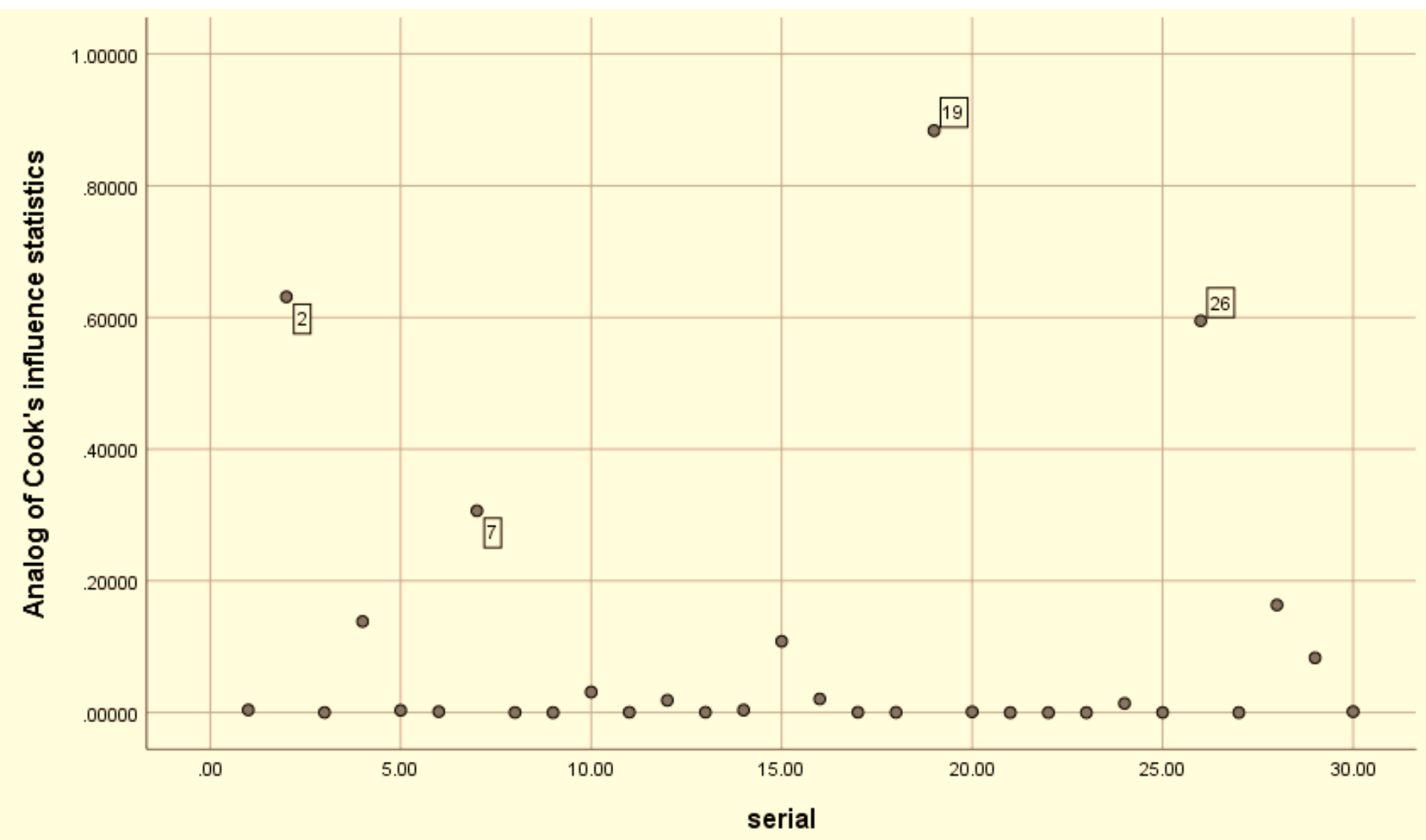

Figure 3

Scatterplot for influential outliers using Cook's test and serial cases 
Independent-Samples Mann-Whitney U Test

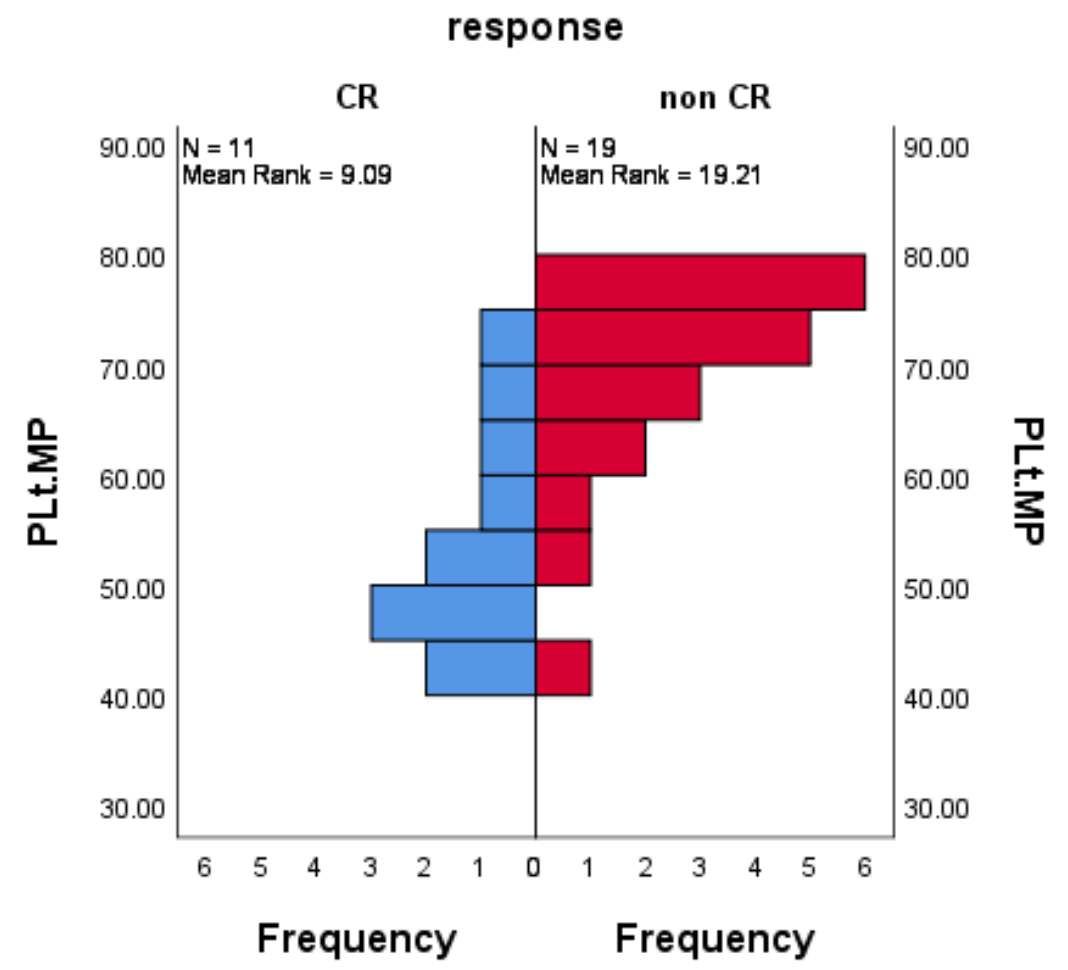

Figure 4

significant difference in PMP among MM patients with $C R$ versus those without $C R, p=0.002$ 
Independent-Samples Mann-Whitney U Test

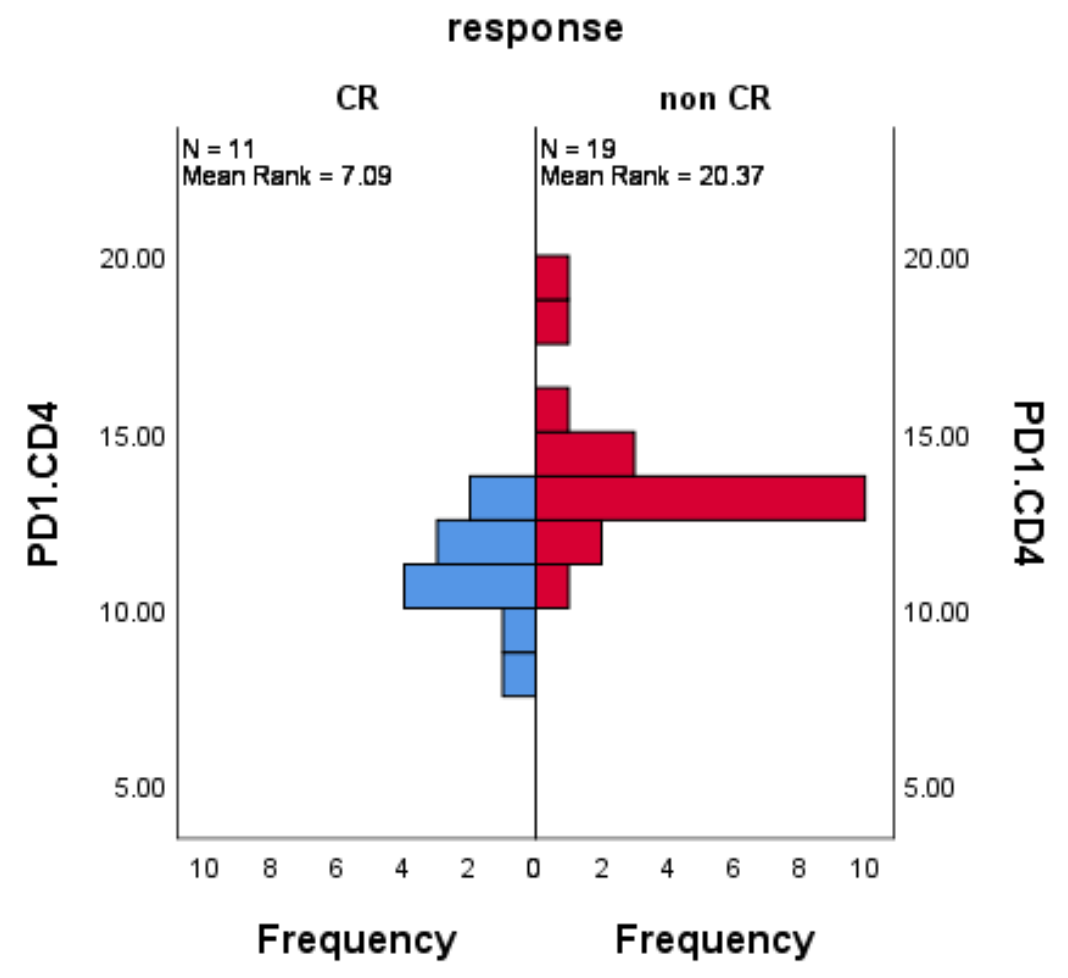

Figure 5

significant difference between MM patients with $\mathrm{CR}$ and those without $\mathrm{CR}$ regarding PD1+CD4+T cells, $\mathrm{P}=0.0001$ 


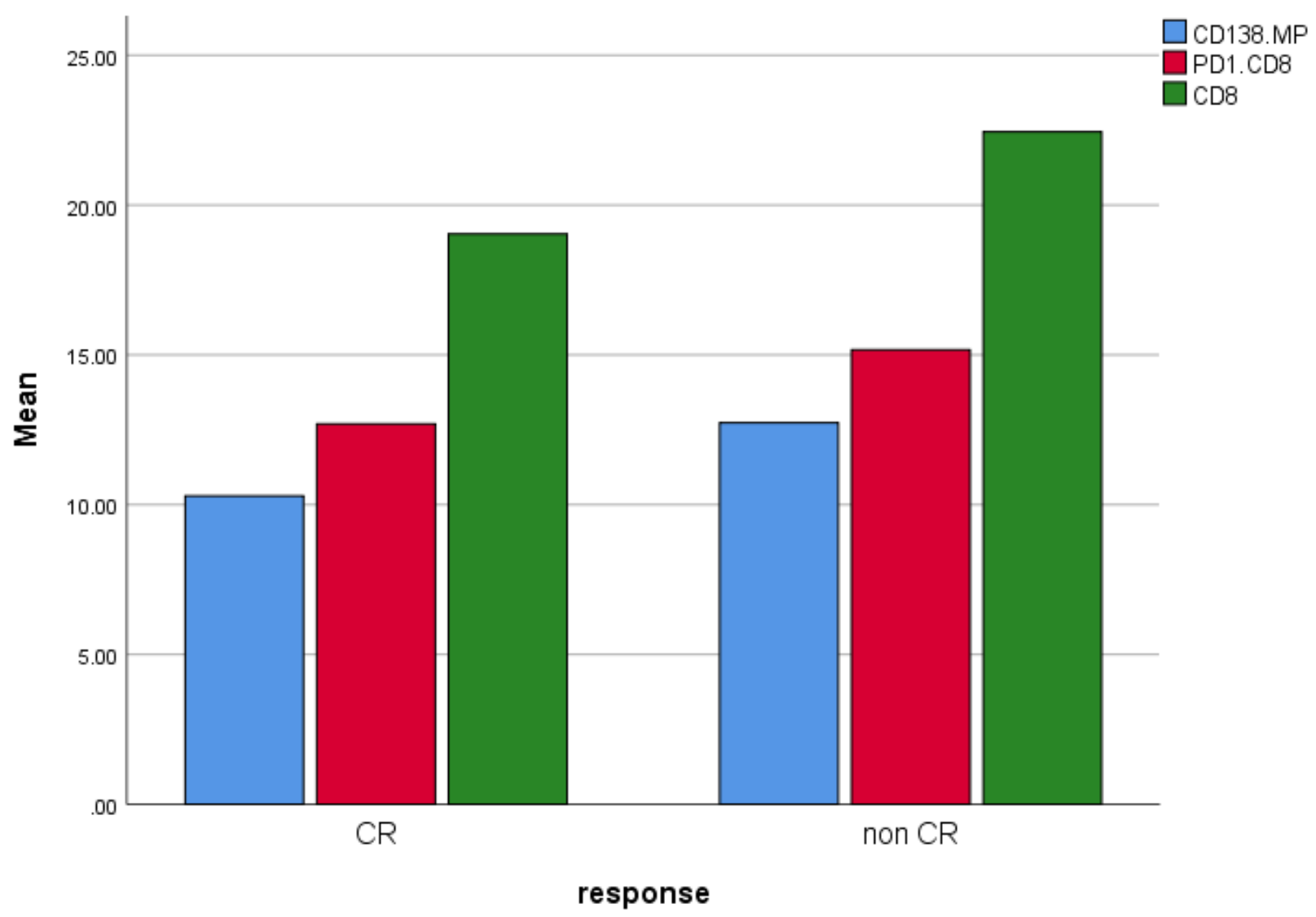

Figure 6

significant difference between response groups of MM patients regarding CD138MP, PD1+CD8+T, and CD8+T cells 


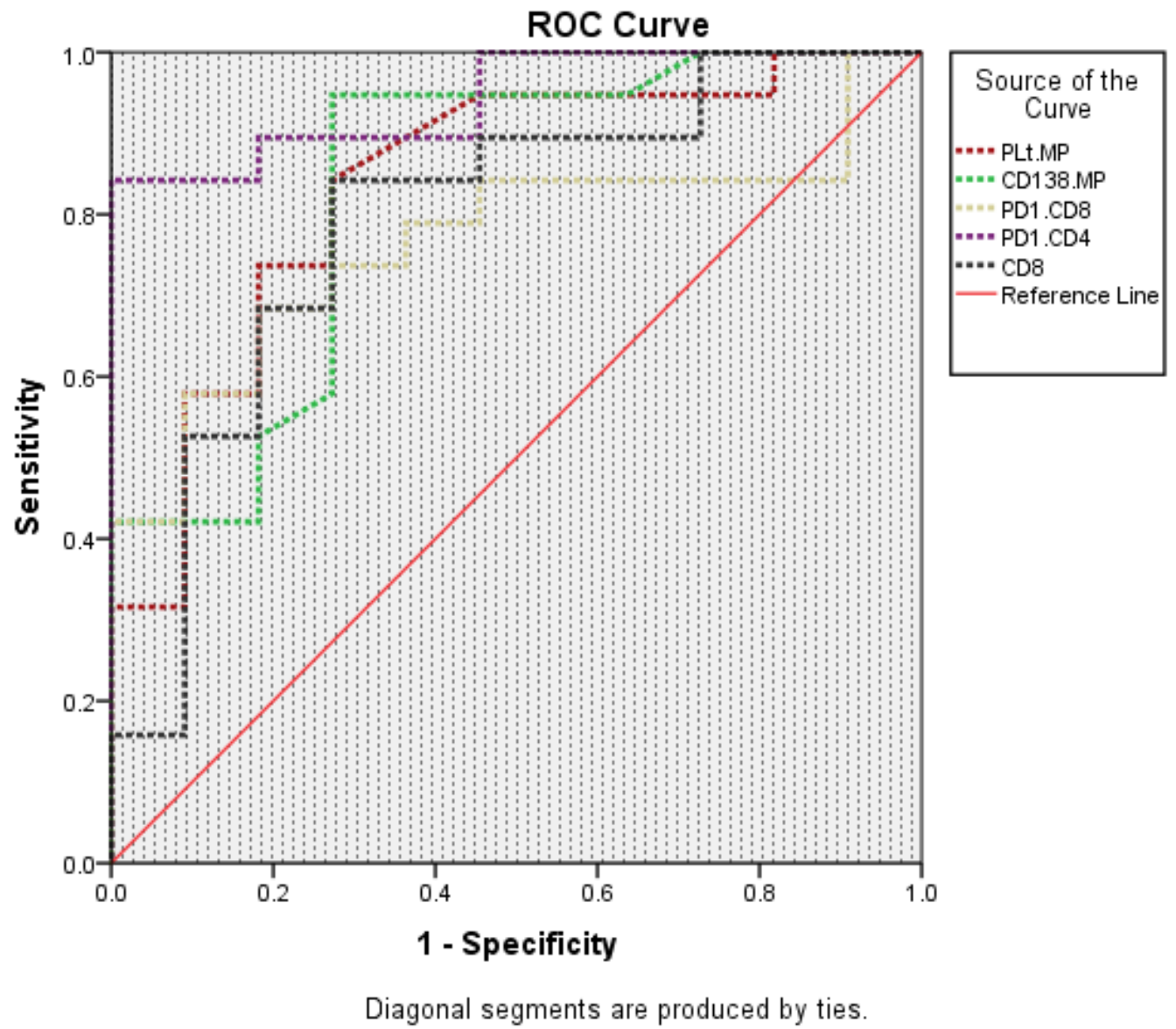

\section{Figure 7}

Receiver operating characteristics (ROC) curve comparing the performance of different MPs and immune cells in the prediction of the response of MM patients 


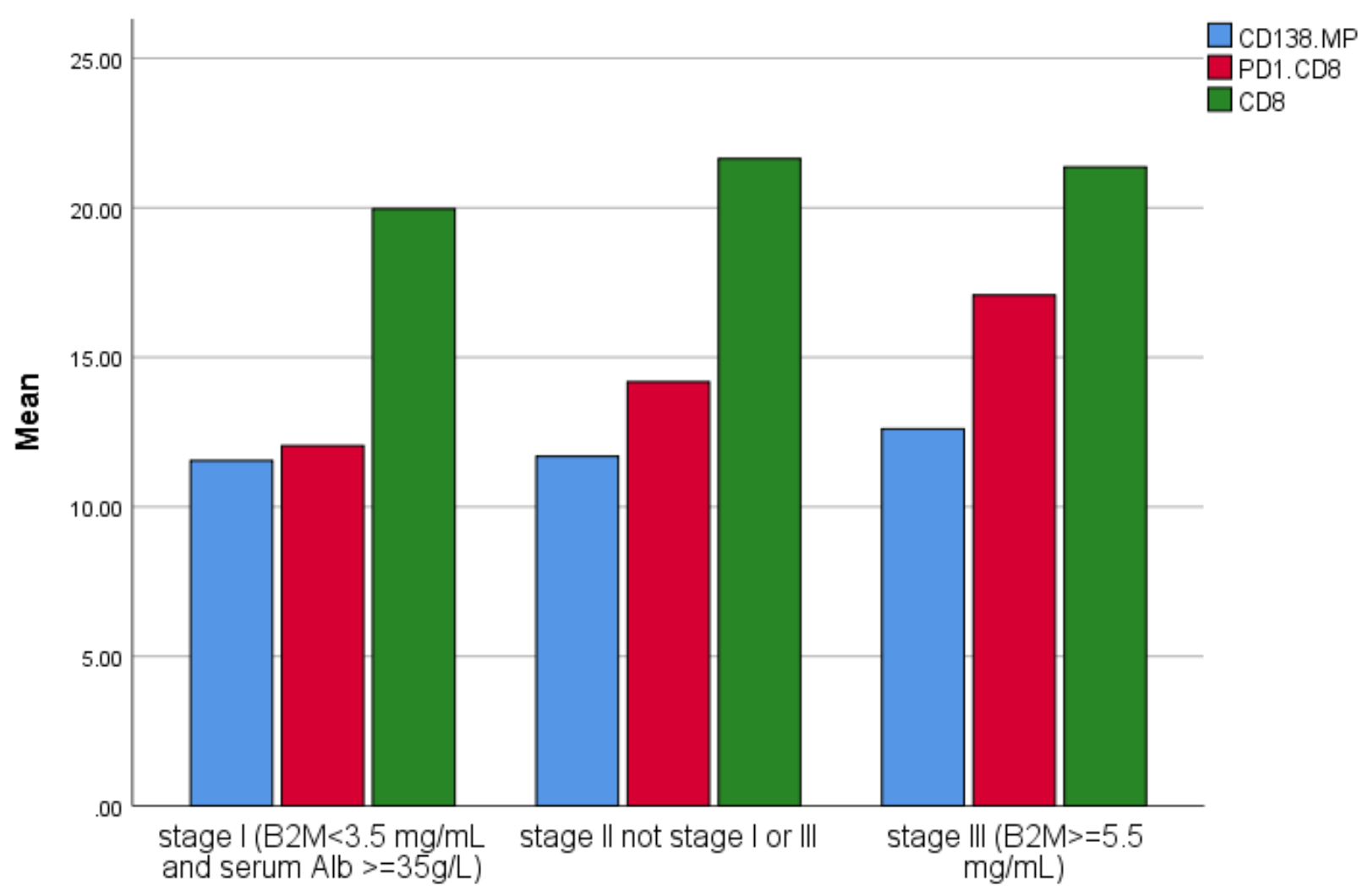

ISS stage

\section{Figure 8}

Tukey HSD for post hoc analysis was applied for PD1+CD $8+T$ cells to detect differences across different ISS stages; significant accumulation of PD1+CD8+T cells was found in stage III compared to stage I (mean difference $=5.04, p=0.001)$, and stage $\|$ (mean difference $=2.9, p=0.018$ ), while no significant difference between stage I and II (mean difference $=2.1, p=0.07$ ). 


\section{Pairwise Comparisons of ISS stage}

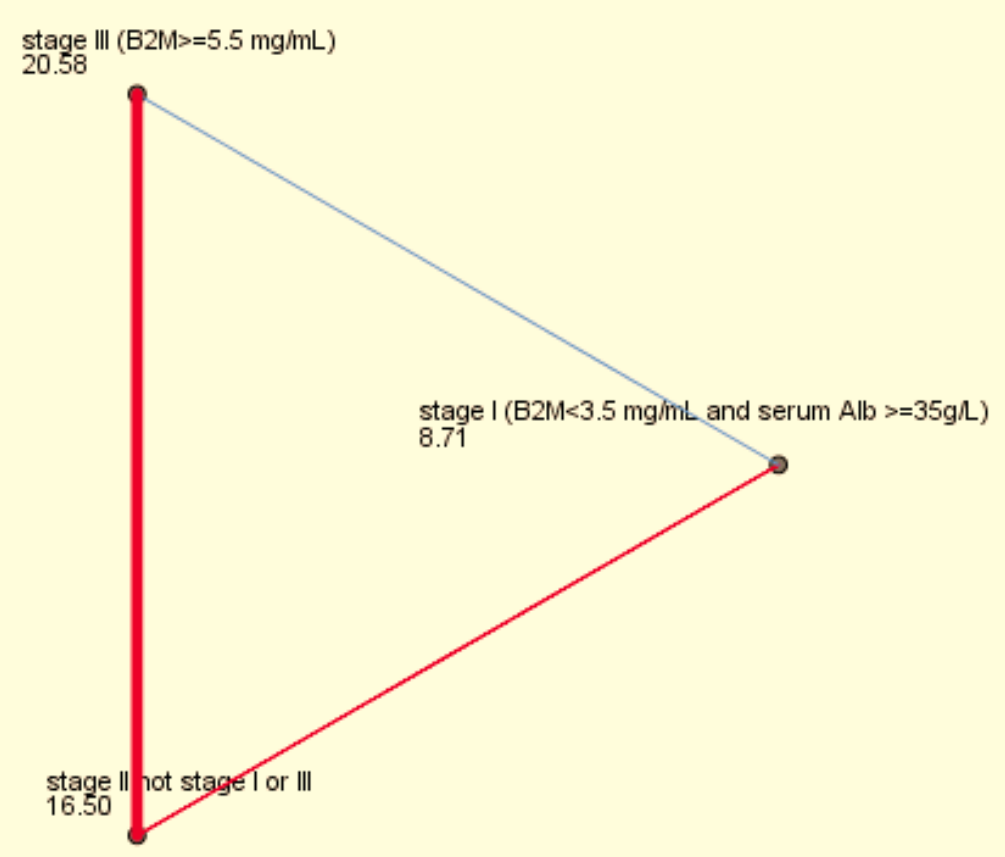

Each node shows the sample average rank of ISS stage.

\section{Figure 9}

Significant accumulation of PD1+CD4+T cells in stages II and III compared to stage I $(p=0.049, p=0.015$ respectively), while no significant differences between stages II \& III ( $p=0.3)$ 